\title{
CORRESPONDENCE
}

\section{DEVONIAN AND CARBONIFEROUS STRATIGRAPHY OF CORNWALL}

SIR,-The stratigraphical comparison between Tintagel and Launceston which has recently been presented by Dr. E. B. Selwood (1961) I feel could be extended, with a fair degree of confidence, as far as the western margin of the Dartmoor granite. Here in the Lydford area, for example, although beds of Gattendorfia Zone age have not yet been identified faunally, the Transition Series (Dearman and Butcher, 1959 ; House, 1959) comprising slates with silty and calcareous beds have afforded palaeontological evidence of the Platyclymenia, Clymenia, and possibly also the Wocklumeria Zones. Between these beds and the Lower Culm cherts there are nearly 400 feet of black shale and silty shale with subordinate lenticles and thin beds of white siltstone.

This unity is also reflected in certain aspects of the structures. It will be recalled that Dr. Gilbert Wilson was the first to be confronted at Boscastle with the possibility of northerly dipping beds in inverted succession when, discussing zigzag folding in the Culm beds at that place, he concluded that "The orientation of these folds in relation to the dip of the bedding suggests inversion of strata" (1951, p. 399). His dilemma, in the absence of other criteria of way-up, has now been resolved by Dr. Selwood's discoveries.

The structural implications of northerly dipping inverted beds at the southern margin of the mid-Devon outcrop of the Culm Measures are :-

(i) The beds may form the upper limb of a syncline closing to the north. If this is so then the fold form is essentially recumbent and "youngs" to the south. Possible attitudes for the lower limb vary from a gentle southerly inclination, through the horizontal, to a slight northerly dip.

(ii) The Tintagel thrusts may be regarded simply as post-folding localized or concentrated continuations of the bedding-plane slip movements necessary to permit the generation of the recumbent fold.

(iii) Recognition of the other bedding attitude-southerly dipping and right way up - may be possible. Alternatively these beds may have been effectively eliminated, as readily recognizable entities, by the rotational effect of penetrative shear movements parallel to the main thrusts.

(iv) It follows, in view of the distribution of the Culm Measures as a whole, that the major structure along the southern margin of the Culm outcrop is an anticlinal fold possibly overturned to the south as suggested by Ashwin (1958) and by Shearman (in discussion on Dearman and Butcher, 1959, p. 90). The recumbent fold postulated above lies on the southern limb of this major anticline, and may be one of a pile of such folds. The northerly down-dip sense of translation of the thrust-bounded masses is not incompatible with such a major structure overturned to the south, that is with a much larger-scale structure having a general southerly sense of translation.

It would be presumptuous to attempt a re-interpretation of the structures, but the horizontal sections given by Dewey (1948, Fig. 9) and Wilson (1951, Fig. 6) do show variations in bedding attitude which would fit in with the picture of sliced-up recumbent folds. The apparently uncomplicated Sections A-B and C-D of Dewey and Wilson's Sections $A$ and $E$ are particularly suggestive in this respect, the more so if the correlation by Batstone (1959) of the Tredorn Phyllites with the Woolgarden Phyllites is accepted and it is further admitted that boundaries between lithological units may be thrust faults.

Northerly dipping inverted strata are well known at other places along the southern margin of the Culm measures. One convincing example may be examined in Red Down Quarry (SX276857) south of Egloskerry where a thin bed of graded tuff shows conclusively that the northerly dipping Culm cherts are inverted. Interpretation of the structures along the north-west margin of the Dartmoor granite by Dearman and Butcher (1959, Fig. 13) involves the deformation, by bedding-plane controlled low-angle normal 
faulting of a pile of angular recumbent folds. In the area there is sufficient evidence based on sedimentary structures to indicate that the northerly dipping beds are inverted. Away from the granite the folds are recumbent. The bedding-plane guided faults are similar in all respects, except exposure, to the Tintagel thrusts, and, along the Dartmoor boundary just as at Tintagel, northerly translations are thought to be predominant.

Department of Geology,

W. R. Dearman.

KING'S COLLEGE, NEWCASTLE-UPON-TYNE, 1.

11th July, 1961.

\section{REFERENCES}

AshwIN, D. P., 1958. The Coastal Outcrop of the Culm Measures of SouthWest England. Abstracts, South-West England Conference, $R$. geol. Soc, Cornwall, 2-3.

Batstone, A. E., 1959. The Structure and Tectonic History of TintagelDavidstow Area. Trans. R. geol. Soc. Cornwall, 19, 17-32.

Dearman, W. R., and N. E. ButCher, 1959. The Geology of the Devonian and Carboniferous Rocks of the North-West Border of the Dartmoor Granite, Devonshire. Proc. Geol. Ass., Lond., 70, 51-92.

Dewey, H., 1948. British Regional Geology, South-West England (2nd ed.). Geol. Surv. and Mus., London.

House, M. R., 1959. Upper Devonian Ammonoids from North-West Dartmoor, Devonshire. Proc. Geol. Ass., Lond., 70, 315-321.

Selwood, E. B., 1961. The Upper Devonian and Lower Carboniferous Stratigraphy of Boscastle and Tintagel, Cornwall. Geol. Mag., 98, 161-167.

WILson, G., 1951. The Tectonics of the Tintagel Area, North Cornwall, Quart. J. geol. Soc., Lond., 106, 393-432.

\section{FIELD RELATIONS OF ROCKS CONTAINING CO-EXISTING PYROXENES.}

SIR,--In the recent discussion in the Geological Magazine concerning co-existing pyroxenes in metamorphic rocks, which has revealed differences of opinion as to the significance of compositional tie-line position, there has been a tendency to use mineral analyses without regard either to the immediate environment of the mineral within the rock or to the field relations of the rock as a whole.

Since five of the rocks referred to variously by Muir and Tilley (1958), O'Hara (1960), and Kretz (1961) come from Scourie, our field investigations in that area (Bowes, Wright, and Park-in press) are relevant. These have shown that the pyroxenites and peridotites described as banded ultrabasic rocks in the North-West Highlands Memoir (Peach et al., 1907) are layered ultrabasic igneous intrusive rocks. They are found in many localities in the Scourie area and their prominent mineralogical banding is unrelated to, and later than, the banding of the surrounding gneisses. A series of similar intrusions has been studied in the Lewisian foreland from Loch Laxford to Loch Torridon and their distribution bears no relation to variations in metamorphic grade.

This field evidence satisfactorily explains the presence at Scourie of the large olivine-contaiing masses regarded by O'Hara (1961) as granulite facies gneisses. It invalidates any conclusions about metamorphic pyroxenes using these rocks as examples and appears to resolve the anomalous $K_{D}$ value (Kretz, op. cit.) for the pyroxenite from Scourie (Muir and Tilley, op. cit., specimen T ; O'Hara, 1960, specimen 7). In the absence of accurate published details of locality, field relations and rock type, we are unable to state with certainty that the rock from Scourie containing the anomalous analysed 